\title{
ARTICLES
}

\section{Interleukin-15 Inhibits Smooth Muscle Cell Proliferation and Hyaluronan Production in Rat Ductus Arteriosus}

\author{
SHIHO IWASAKI, SUSUMU MINAMISAWA, UTAKO YOKOYAMA, TORU AKAIKE, HONG QUAN, YOJI NAGASHIMA, \\ SHIGERU NISHIMAKI, YOSHIHIRO ISHIKAWA, AND SHUMPEI YOKOTA
}

\begin{abstract}
Department of Pediatrics [S.I., S.N., S.Y.], Department of Pathology [Y.N.], Yokohama City University, Yokohama 236-0004, Japan; Cardiovascular Research Institute [S.M., U.Y., T.A., H.Q., Y.I.], Yokohama City University Graduate School of Medical Science, Yokohama 236-0004, Japan; Departments of Cell Biology \& Molecular Medicine and Medicine (Cardiology) [Y.I.], Cardiovascular Research Institute, New Jersey Medical School, Newark, NJ 07103
\end{abstract}

\begin{abstract}
Neointimal cushion formation (NCF) is an important vascular remodeling for anatomical closure of the ductus arteriosus (DA). Inflammatory responses to vascular injury or atherosclerosis are known to be associated with the pathogenesis of NCF. We found that the expression of interleukin (IL)-15 mRNA was significantly higher in rat DA than in the aorta. IL-15 immunoreactivity was detected predominantly in the internal elastic laminae (IEL) and to a lesser extent in smooth muscle cells (SMCs) in rat DA. Prostaglandin E (PGE) increased the expression of IL-15 mRNA in cultured DA SMCs. IL-15 significantly attenuated the platelet-derived growth factor (PDGF)-BB-mediated SMC proliferation, but did not change SMC migration. IL-15 significantly attenuated $\mathrm{PGE}_{1}$-induced hyaluronic acid (HA) production in a dose-dependent manner, which is a potent stimulator of NCF. Accordingly, IL-15 might have an inhibitory effect on the physiologic vascular remodeling processes in closing the DA. (Pediatr Res 62: 392-398, 2007)
\end{abstract}

$\mathrm{T}$ he ductus arteriosus (DA), a fetal arterial connection between the main pulmonary artery and the descending aorta, closes immediately after birth. During the first few hours after birth in term newborns, there is acute and functional closure as a result of the DA's smooth muscle contraction, which is triggered by an increase in oxygen tension and a decline in circulating prostaglandin $\mathrm{E}\left(\mathrm{PGE}_{2}\right)$ (1). It is important that before this, an anatomical luminal narrowing develops through neointimal cushion formation (NCF) that occludes the vascular lumen and gives rise to a permanent closure $(2,3)$. The neointimal cushion of DA is formed by many cellular processes, including smooth muscle cell (SMC) migration and proliferation, extracellular matrix production under the endothelial layer, and decreased elastin fiber assembly (1-5). It is interesting that this physio-

Received November 28, 2006; accepted May 10, 2007.

Correspondence: Susumu Minamisawa, M.D., Ph.D., Cardiovascular Research Institute, Yokohama City University Graduate School of Medical Science, 3-9 Fukuura, kanazawa-ku, Yokohama 236-0004, Japan; e-mail: sminamis@med.yokohama-cu.ac.jp.

This work was partly supported by the grant for the 2005 Strategic Research Project of Yokohama City University (S.M.), the Yokohama Foundation for Advanced Medical Science (S.I., U.Y., T.A., Y.I.), the Ministry of Education, Science, Sports and Culture of Japan (Y.I.), the Grant-in-Aid for Scientific Research (Y.N.), the Miyata Cardiology Research Promotion Funds (S.M.), and the Foundation for Growth Science (S.M.). logic process of NCF in the DA closely resembles the pathologic process of NCF caused by vascular injury or atherosclerosis in adult arteries (6).

Inflammatory responses to vascular injury or atherosclerosis are known to be associated with the pathogenesis of NCF (7-9). Recent studies have demonstrated that several proinflammatory cytokines play an essential role during such vascular remodeling $(10,11)$. Accordingly, cytokines might play a role in physiologic vascular remodeling processes and thus permanent closure in the DA. In this regard, Waleh et al. (12) demonstrated that after postnatal constriction, certain types of cytokines were associated with the accumulation of monocytes/macrophages on the ductus wall that may regulate neointimal remodeling. However, a limited number of studies investigated the relationship between cytokine and DA closure (12-14), and the precise role of cytokines in the vascular remodeling process in DA remains poorly understood. It is important that perinatal inflammation sometimes retards the postnatal closure of the DA (15), although the mechanism has not been fully understood. Further maternal infection such as rubella causes congenital patent DA in a child (16). Using DNA microarray analysis, we found that the expression of IL-15, a proinflammatory cytokine, was significantly higher in the DA than in the aorta (unpublished data). IL-15 exhibits many immunologic actions such as stimulation of T-cell proliferation and chemotaxis, natural killer cell growth, secretion of interferon-gamma (IFN- $\gamma$ ), granulocyte/macrophage colonystimulating factor, and tumor necrosis factor $\alpha$ (TNF- $\alpha$ ) (1719). Because IL-15 has been detected in atherosclerotic plaques $(20,21)$ and attenuates NCF after arterial injury (22), we investigated the role of IL-15 in the physiologic vascular remodeling of the DA.

\footnotetext{
Abbreviations: DA, ductus arteriosus; e21, embryonic day 21; EP4, prostaglandin E receptor subtype 4; GAPDH, glyceraldehyde-3-phosphate dehydrogenase; HA, hyaluronic acid; IEL, internal elastic laminae; IL-15R $\boldsymbol{\alpha}$, interleukin-15 receptor $\alpha$; NCF, neointimal cushion formation; PGE, prostaglandin E; SMC, smooth muscle cell
} 
Table 1. Oligonucleotides for quantitative RT-PCR

\begin{tabular}{|c|c|c|c|c|}
\hline Gene & GenBank accession number & Forward $\left(5^{\prime}-3^{\prime}\right)$ & Reverse $\left(5^{\prime}-3^{\prime}\right)$ & Size (bp) \\
\hline$I L-15$ & NM_013129 & CGTGCTCTACCTTGCAAACA & TCAACCGTTTCCTGTTAGGC & 271 \\
\hline$I L-15 R \alpha$ & XM_344628 & GTGTGAACTCCAGGGAGAGG & AGGTTGGGAGTTGTCCAGTG & 124 \\
\hline$I L-2 R \beta$ & NM_013195 & GACGTCTTCTGGACCGTAGC & CTTAGGATCTGCTGGCCTTG & 200 \\
\hline fractalkine & NM_134455 & CCTTGCTCATCCACTATCAAC & CTTGGACCCATTTCTCCTT & 114 \\
\hline CX3CR1 & NM_133534 & CTGCTCAGGACCTCACCAT & CAGACCGAACGTGAAGACAA & 158 \\
\hline EP4 & NM_032076 & $\begin{array}{l}\text { Primer name: TaqManR Gene Expression } \\
\text { Assays (Rn00583420 m1) }\end{array}$ & & Unknown \\
\hline
\end{tabular}

\section{METHODS}

Reagents. Rat IL-15 and IL-2 were from IBL Co., Ltd. (Gunma, Japan). $\mathrm{PGE}_{1}$ was from Calbiochem (La Jolla, CA). IL-6, IL-8, soluble TNF receptor 1 , IFN- $\gamma$, transforming growth factor $\beta$ (TGF $\beta$ ), TNF- $\alpha$, IL- $1 \beta$, IL- 10 , and vascular endothelial growth factor were from Pepro Tech EC, Inc. (Rocky Hill, NJ). Indomethacin was from Wako Pure Chemical Industries, Ltd. (Osaka, Japan). PGE receptor subtype 4 (EP4) specific agonist ONO-AE1329 was from ONO Pharmaceutical Inc. (Tokyo, Japan). Elastica-van Gieson stain was from Muto Pure Chemicals Co., Ltd. (Tokyo, Japan). TaqMan rodent glyceraldehyde-3-phosphate dehydrogenase (GAPDH) control reagents kits were from Applied Biosystems (Foster City, CA). Rabbit antimouse IL-15, IL-2 receptor $\beta$ (IL-2R $\beta$ ), and IL-2 receptor $\gamma($ IL-2R $\gamma$ ) antibodies and goat anti-mouse IL-15 receptor $\alpha$ (IL-15R $\alpha$ ) antibodies were from Santa Cruz Biotechnology, Inc. (Santa Cruz, CA). Biotinylated goat anti-rabbit secondary antibody and biotinylated rabbit anti-goat secondary antibody were from Histofine, Nichirei (Tokyo, Japan).

Animals. All animals were cared for in compliance with the guiding principles of the American Physiologic Society. The experiments were approved by the Ethics Committee of Animal Experiments of the Yokohama City University School of Medicine. We used Wistar rat embryos from timed pregnant mothers.

Quantitative and semiquantitative transcriptase [reverse-transcriptase polymerase chain reaction (RT-PCR)]. The total RNA was isolated from the pooled tissues of one littermate of Wistar rat embryos. A generation of cDNA and RT-PCR analysis was done as described previously (23). The primers for PCR amplification were designed as based on the rat nucleotide sequences (Table 1). For quantitative RT-PCR analysis, each template was tested four to nine times to confirm the reproducibility of the assays. The abundance of each gene was determined relative to GAPDH.

Immunohistochemistry. Paraffin-embedded blocks containing DA tissue were cut into 4- $\mu \mathrm{m}$ thick sections and placed on 3-aminopropyltriethoxysilane-coated glass slides. To determine the boundary line of intimal cushion formation, tissue sections were stained with elastica-van Gieson as recommended by the manufacturer (Muto Pure Chemicals).

The specimens were deparaffinized, rehydrated, and incubated for $30 \mathrm{~min}$ in $0.3 \%$ hydrogen peroxide to inactivate endogenous peroxidases. Tissue sections for IL-15 were incubated with pepsin for $30 \mathrm{~min}$ at $37^{\circ} \mathrm{C}$ for restoring immunoreactivity to tissue antigens. To reduce nonspecific background staining, $10 \%$ goat serum for IL- 15 , IL-2R $\beta$, and IL-2R $\gamma$ and $10 \%$ rabbit serum for IL-15R $\alpha$ were used at $37^{\circ} \mathrm{C}$ for $15 \mathrm{~min}$. For immunohistochemical staining, a rabbit anti-mouse antibody for IL-15, IL-2R $\beta$, and IL-2R $\gamma$ and a goat anti-mouse antibody for IL-15R $\alpha$ were used at $4{ }^{\circ} \mathrm{C}$ for overnight and then incubated with a biotinylated secondary antibody at room temperature for 10 min. The slides were sequentially incubated with streptavidin peroxidase at room temperature for $5 \mathrm{~min}$ and diaminobenzidine chromogen substrate solution and were counterstained.

Cell culture and stimulation. Vascular SMCs in primary culture were obtained from the DA and the aorta of Wistar rat embryos at embryonic day 21 (e21), as described previously (23). The confluent cells between passages 4 and 6 were used in the experiments. To examine the effect of EP4 or IL-15, SMCs were exposed to ONO-AE1-329 $\left(10^{-6} \mathrm{M}\right)$ or IL-15 $(50 \mathrm{ng} / \mathrm{mL})$ for $2-4 \mathrm{~h}$ and then collected with Trizol (Invitrogen, Tokyo, Japan) for further analysis.

Cell proliferation assays. Cell proliferation was measured in DA SMCs using $\left[{ }^{3} \mathrm{H}\right]$ thymidine incorporation, as described previously (23).

Quantitation of hyaluronic acid $(\boldsymbol{H A})$. The amount of HA in the cell culture supernatant was measured by a latex agglutination method as described previously (24).

SMC migration assay. The migration assay was performed using 24-well Transwell culture inserts with polycarbonate membranes (8- $\mu \mathrm{m}$ pores: Corning Inc., Acton, MA) as described previously with some modifications (24).
Statistical analysis. All data are presented as means \pm SD. Unpaired $t$ tests were used to compare mRNA expression in the DA and other tissues. Comparisons between data from multiple groups were performed by unpaired analysis of variance followed by the Student-Newman-Keuls test. $p$ Values $<0.05$ were considered statistically significant.

\section{RESULTS}

Expression of $I L-15$ and $I L-15$ receptors in rat DA. Our DNA microarray analyses revealed that the expression level of IL-15 mRNA was greater in the DA than in the aorta during development (unpublished data). The present quantitative RTPCR analyses confirmed the higher expression levels of IL-15 in the DA than in the aorta at all developmental stages. The

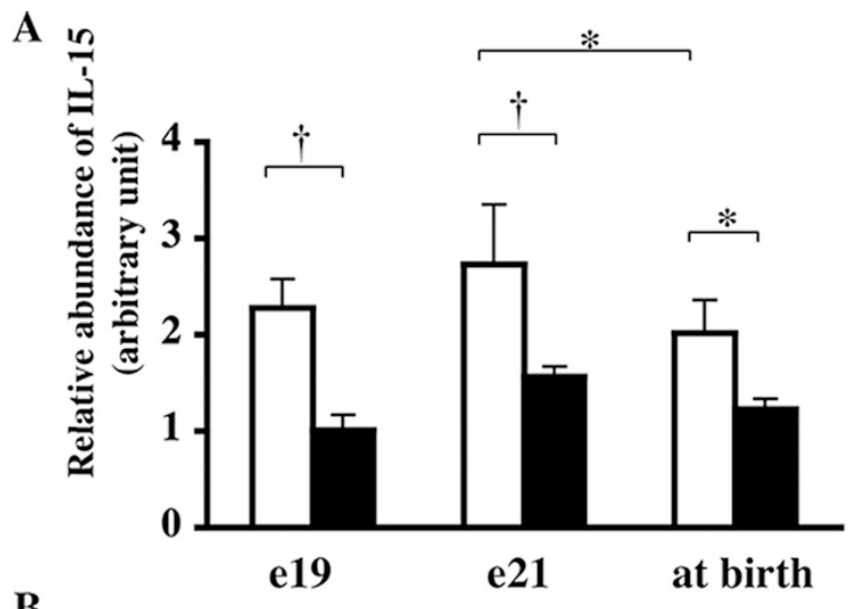

B

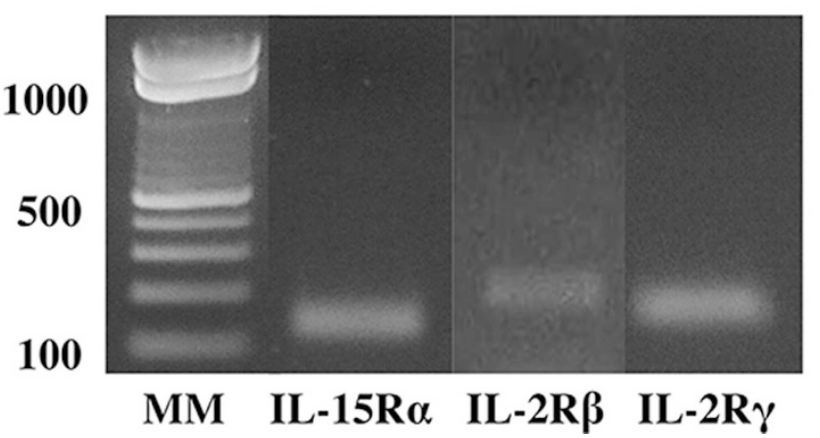

Figure 1. Expressions of IL-15 and its receptors in DA. (A) Quantitative RT-PCR for IL-15 in rat DA and aorta at e19, e21, and birth. The expression of IL-15 mRNA was greater in rat DA (open columns) than in aorta (solid columns) at all developmental stages examined. The IL-15 expression in the DA reached maximum at e21 $(n=4)$. The values are expressed as mean \pm SD. $* p<0.05$ and $\dagger p<0.001$. (B) RT-PCR of receptors for IL-15 in rat DA. The trimetric IL-15 receptor complex consists of IL-15R $\alpha$, IL-2R $\beta$, and IL-2R $\gamma$. All three receptors were expressed in DA tissues. 

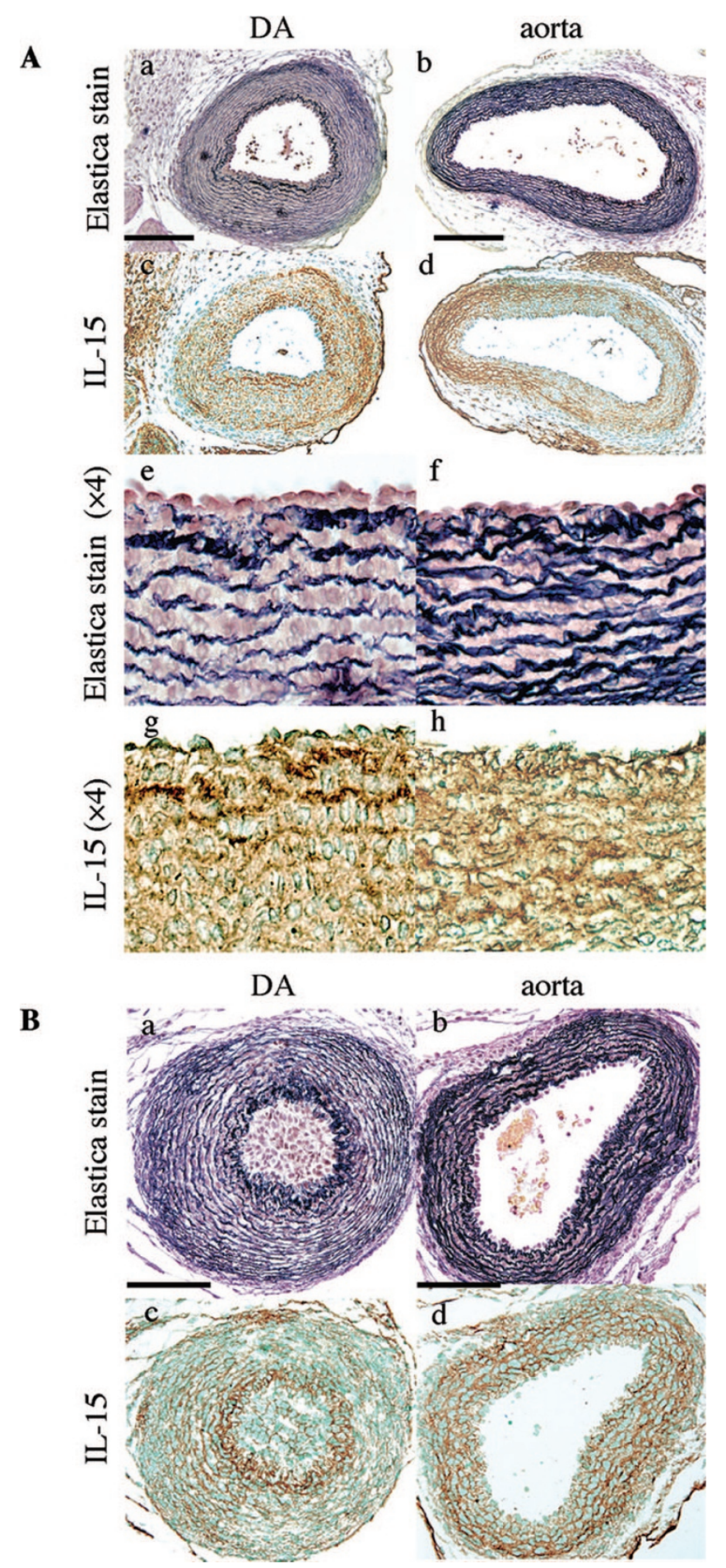

Figure 2. Localization of IL-15 in DA. (A, B) Transverse sections of the DA and aorta at $\mathrm{e} 21$ and birth, respectively. An elastica-van Gieson stain visualized elastic fibers in the DA ( $A-a, b, e, f, B-a, b)$. IL-15 immunoreactivity (brown chromogen) was detected predominantly in the IEL and to a lesser extent in SMCs in the DA $(A-c, g, B-c)$. Conversely, immunostaining of this strength was not observed in the IEL of the aorta $(A-d, h, B-d)$. Scale bars, 100 $\mu \mathrm{m}$.

expression levels of IL-15 became maximal at e21 (full term) in the DA (Fig. 1A). Because IL-15 uses a trimeric receptor consisting of IL-15R $\alpha$, IL-2R $\beta$, and IL-2R $\gamma$, we examined the expression of them in the DA. We found that the mRNAs of all these receptors were expressed in DA tissues (Fig. 1B) as

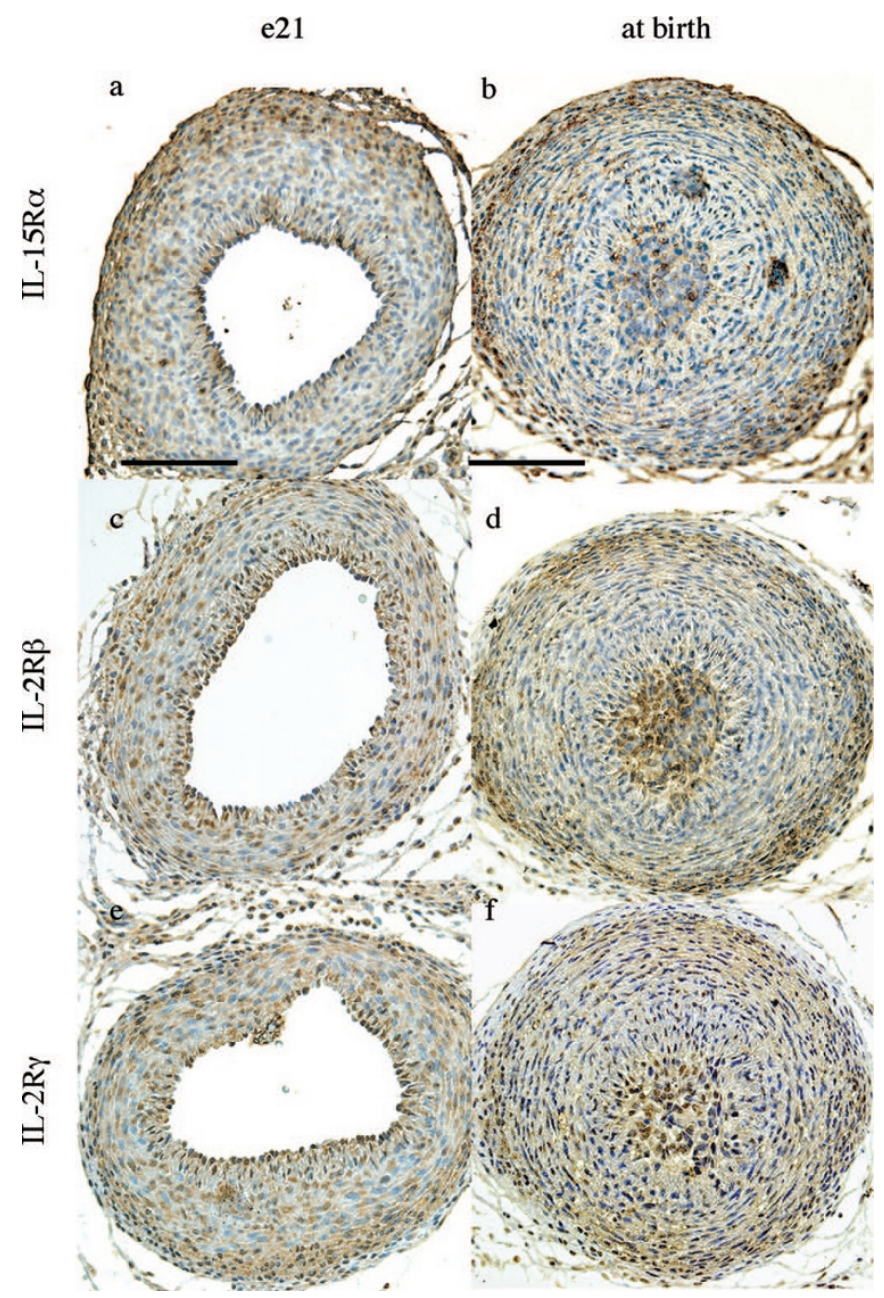

Figure 3. Localization of IL-15 receptors in the DA. Transverse sections of DA at e21 and at birth, respectively. The immunoreactivity of IL-15 receptors (brown chromogen) did not exhibit a similar expression pattern with IL-15 in the DA. Scale bars, $100 \mu \mathrm{m}$.

well as in primary cultured SMCs from rat DA. The expression of IL-2R $\alpha$ mRNA was not detected in the DA (data not shown).

We then examined the localization of IL-15 in the DA and aorta at e21 and birth. IL-15 immunoreactivity was detected most abundantly in the internal elastic laminae (IEL), less abundantly in SMCs, and even less in the endothelial cells of the DA at e21 (Fig. 2A). It is interesting that the abundant immunostaining of IL-15 was not observed in the IEL of the aorta in the same sections and was rather strong in the adventitia (Fig. 2A). At birth, the DA's lumen was filled with cells that were mostly of SMC origin. The immunoreactivity of IL-15 in the IEL of the DA became more apparent, whereas only weak immunostaining was detected in the IEL of the aorta (Fig. 2B). Furthermore, we examined the localization of IL-15R $\alpha$, IL-2R $\beta$, and IL-2R $\gamma$ in DA. None of the IL-15 receptors exhibited the same localization with IL-15. They were strong in the region of the inner layer of DA at e21 and in the region of the central core of the lumen at birth (Fig. 3).

Positive feedback loop of the expression between IL-15 and EP4. Because the expression of EP4 mRNA was also maximal at e21 in the DA (24) and because previous studies 

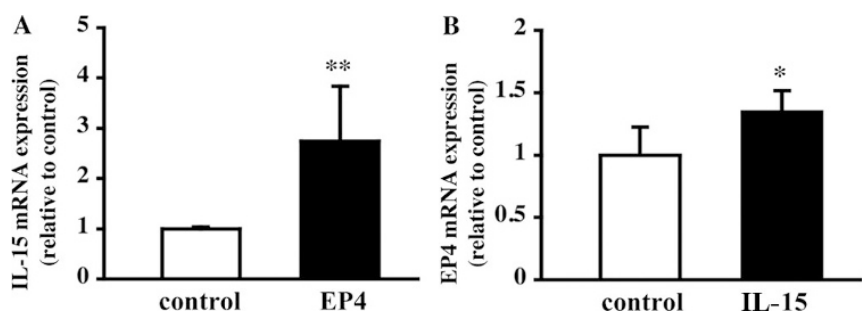

Figure 4. (A) The expression of IL-15 was markedly increased in DA SMCs cultured with a selective EP4 agonist, ONO-AE1-329 $\left(10^{-6} \mathrm{M}\right)$, compared with control $(n=4)$. (B) The expression of EP4 was significantly increased in DA SMCs cultured with IL-15, compared with control $(n=9)$. Values are expressed as mean \pm SD. $* p<0.05 ; * * p<0.01$.

have demonstrated that PGE regulated the expression of IL-15 in various types of cells (25-27), we hypothesized that EP4 stimuli may regulate the expression of IL-15 mRNA or vice versa. By using cultured DA SMCs, we found that ONO-AE1$329\left(10^{-6} \mathrm{M}\right)$, a selective EP4 agonist, markedly increased the expression of IL-15 mRNA (Fig. 4A). Recombinant rat IL-15 $(50 \mathrm{ng} / \mathrm{mL})$ significantly increased the expression of EP4 mRNA after $2 \mathrm{~h}$ in cultured DA SMCs (Fig. $4 B$ ).

Effect of IL-15 on DA SMC proliferation. SMC proliferation plays an essential role in NCF in developing the DA, especially in the late gestation. Therefore, we investigated the effects of IL-15 on proliferation using DA SMCs in primary culture from rat DA at e21. $\left[{ }^{3} \mathrm{H}\right]$ Thymidine incorporation was moderately, but significantly, decreased in DA SMCs in the presence of recombinant rat IL-15 $(50 \mathrm{ng} / \mathrm{mL})$ when compared with that in the absence of IL-15 (Fig. 5A). When DA SMCs were treated with PDGF-BB $(10 \mathrm{ng} / \mathrm{mL})$, a potent stimulator of SMC proliferation, $\left[{ }^{3} \mathrm{H}\right]$ thymidine incorporation was significantly increased by $19 \%$ in DA SMCs. IL-15 significantly attenuated the PDGF-BB-mediated increase in $\left[{ }^{3} \mathrm{H}\right]$ thymidine incorporation in DA SMCs (Fig. 5A), suggesting that IL-15 inhibits DA SMC proliferation.

Because our recent study demonstrated that $\mathrm{PGE}_{1 / 2}$ plays important roles not only in regulating vascular tone, but also in the vascular remodeling process in the DA (24), we investigated the synergistic effect of IL-15 on DA SMC proliferation in the presence of $\mathrm{PGE}_{1}$. $\mathrm{PGE}_{1}$ significantly decreased $\left[{ }^{3} \mathrm{H}\right]$ thymidine incorporation in a dose-dependent manner. IL-15 additively reduced $\left[{ }^{3} \mathrm{H}\right]$ thymidine incorporation in DA SMCs (Fig. 5B). We also found that IL15 reduced $\left[{ }^{3} \mathrm{H}\right]$ thymidine incorporation by $14 \pm 2 \%$, even in the presence of indomethacin $\left(10^{-6} \mathrm{mg} / \mathrm{mL}\right.$ ), a cyclooxygenase inhibitor (Fig. $5 A$ ). These results suggest that the inhibitory effect of IL-15 on SMC proliferation is independent of the PGE pathway.

Because IL-15 and IL-2 have similar biological activities through binding to the common IL-2R $\beta$ and IL-2R $\gamma$, we investigated the effect of IL-2 on DA SMC proliferation. IL-2 (up to $30 \mathrm{ng} / \mathrm{mL}$ ) had no significant effect on $\left[{ }^{3} \mathrm{H}\right]$ thymidine incorporation in DA SMCs (data not shown), which may be expected because IL-2R $\alpha$ was absent in DA.

Effects of IL-15 on DA SMC migration. Because SMC migration from vascular media into the subendothelial layer is an important vascular remodeling process of NCF, we investigated the effects of IL-15 on DA SMC migration. IL-15 (50
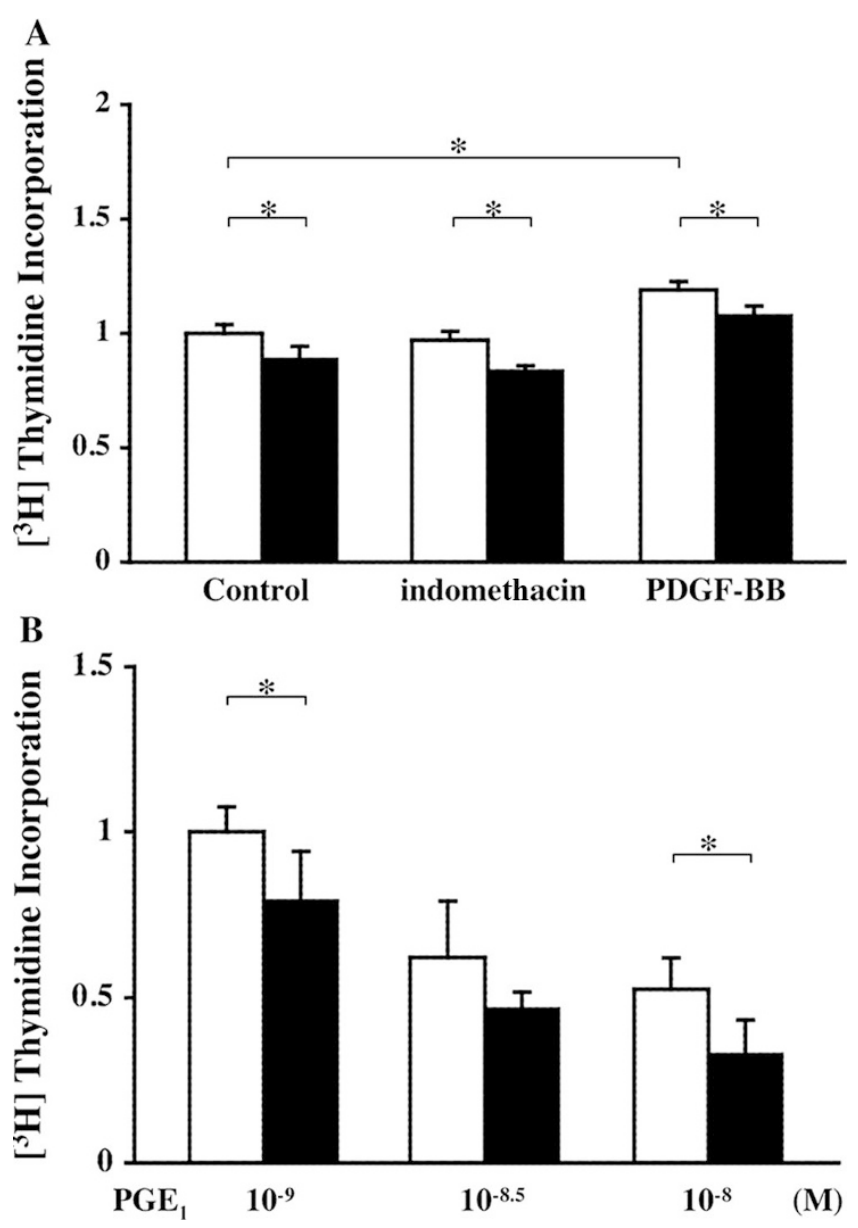

Figure 5. IL-15 significantly reduced DA SMC proliferation. $\left[{ }^{3} \mathrm{H}\right]$ Thymidine incorporation was compared with IL-15 (solid columns) and without IL-15 (open columns). (A) IL-15 significantly decreased $\left[{ }^{3} \mathrm{H}\right]$ thymidine incorporation in rat DA SMC at a concentration of $50 \mathrm{ng} / \mathrm{mL}$ when compared with control. This effect did not change in the presence of indomethacin $\left(10^{-6}\right.$ $\mathrm{mg} / \mathrm{mL})$. PDGF-BB $(10 \mathrm{ng} / \mathrm{mL})$-mediated increases in $\left[{ }^{3} \mathrm{H}\right]$ thymidine incorporation were also attenuated by $50 \mathrm{ng} / \mathrm{mL}$ of IL-15 ( $n=19$, control; $n=4$, indomethacin, PDGF-BB). (B) $\left[{ }^{3} \mathrm{H}\right]$ Thymidine incorporation was decreased by $\mathrm{PGE}_{1}$ in a dose-dependent manner. IL-15 exhibited an additive inhibitory effect on $\mathrm{PGE}_{1}$-mediated decreases in $\left[{ }^{3} \mathrm{H}\right]$ thymidine incorporation $(n=4)$. Values are expressed as mean $\pm \mathrm{SD}$. ${ }^{*} p<0.05$.

$\mathrm{ng} / \mathrm{mL}$ ) exhibited no significant effect on SMC migration either in the absence or presence of PDGF-BB (10 ng/mL) (Fig. 6).

Effect of IL-15 on HA production in DA SMCs. HA is an important component of the intimal cushion, and HA-rich matrices are essential for cell migration and proliferation in the DA (24). Because a previous study demonstrated that IL-15 increased HA expression in the endothelial cells (28) and because our recent study uncovered that $\mathrm{PGE}_{1}$ is a potent stimulator of HA production in DA SMCs (24), we investigated whether IL-15 altered basal and $\mathrm{PGE}_{1}$-induced HA production in DA SMCs. Although IL-15 had no effect on basal HA production, it significantly attenuated $\mathrm{PGE}_{1}$-induced HA production in a dose-dependent manner (Fig. $7 A, B$ ). We have demonstrated that TGF $\beta$ significantly increased HA production in DA SMCs (24) and that IL-6, IL-8, and soluble TNF receptor 1 were significantly elevated in the cord blood of premature infants with chronic lung disease (29). Therefore, we also investigated the effects of other cytokines. In the 


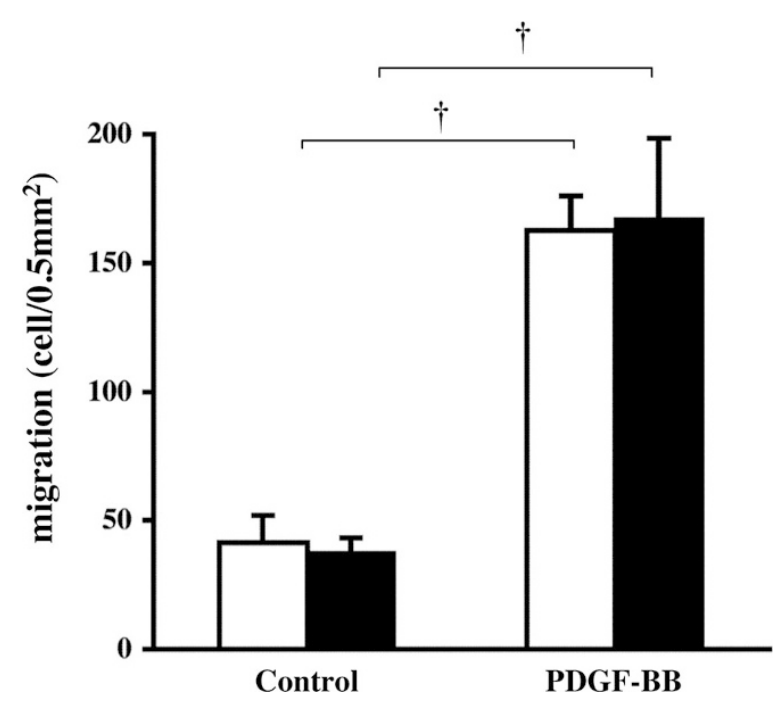

Figure 6. IL-15 has no influence on DA SMC migration. DA SMC migration in response to IL-15 $(50 \mathrm{ng} / \mathrm{mL})$ in the presence or absence of PDGF-BB (10 $\mathrm{ng} / \mathrm{mL})$. IL-15 did not significantly affect DA SMC migration. IL-15-treated DA SMC (solid columns), IL-15-untreated DA SMC (open columns) $(n=4)$. Values are expressed as mean $\pm \mathrm{SD} . \dagger p<0.001$.
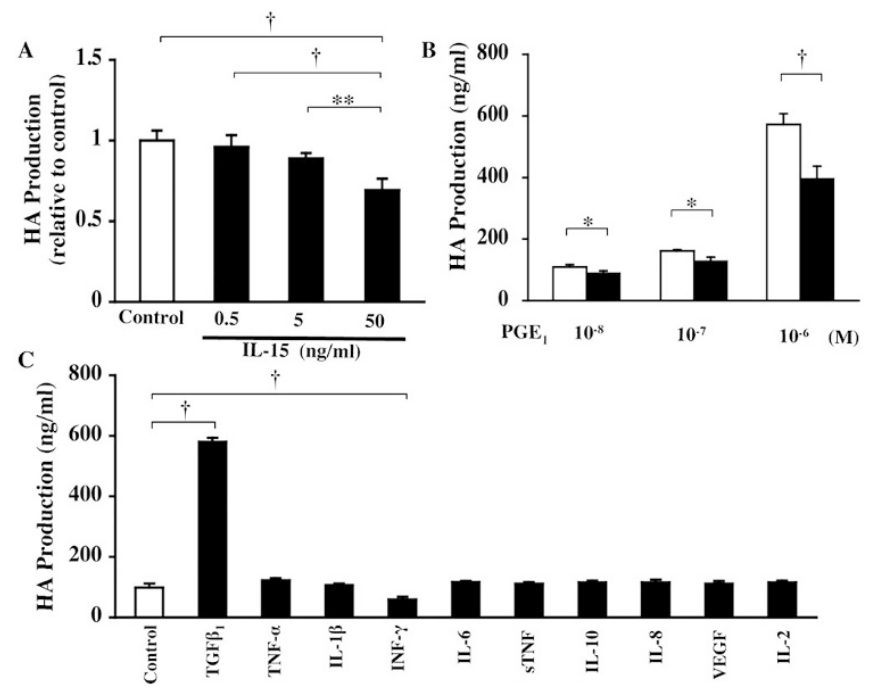

Figure 7. IL-15 significantly reduced HA synthesis of DA SMCs. HA secretion into culture media after $48 \mathrm{~h}$ of stimulation. Because HA synthesis was very low in untreated DA SMCs, we examined the effect of several cytokines including IL-15 on HA production in $\mathrm{PGE}_{1}$-stimulated DA SMCs. (A) HA synthesis was reduced by IL-15 in a dose-dependent manner $(n=4)$. (B) PGE $_{1}$ induced HA synthesis in a dose-dependent manner. IL-15 significantly reduced $\mathrm{PGE}_{1}$-mediated $\mathrm{HA}$ synthesis, especially at high concentrations of $\mathrm{PGE}_{1}$. IL-15 treated DA SMCs (solid columns), IL-15 untreated DA SMCs (open columns) $(n=4)$. (C) The effect of several cytokines on HA production in $\mathrm{PGE}_{1}$-stimulated DA SMCs $(n=3)$. Values are expressed as mean \pm SD. $* p<0.05 ; * * p<0.01 ; \dagger p<0.001$.

basal condition, these cytokines (except TGF $\beta$ ) had no effect on HA production in DA SMCs. Only IFN- $\gamma$ slightly decreased HA production in the presence of $\mathrm{PGE}_{1}$ (Fig. $7 C$ ). Although the stimulatory effect of TGF $\beta$ was much weaker in DA than that of $\mathrm{PGE}_{1}$ in the basal condition (24), a marked increase in HA production was induced by coincubation of $\mathrm{TGF} \beta$ and $\mathrm{PGE}_{1}$.

Effect of IL-15 on the expression of fractalkine and CX3CR1 mRNA. Because IL-15 is known to suppress
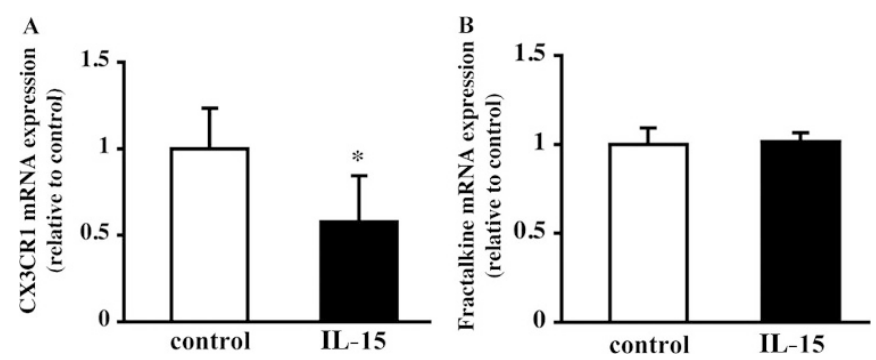

Figure 8. IL-15 significantly decreased the expression of CX3CR1 (A), but not fractalkine $(B)$ mRNA in DA SMCs $(n=5, \mathrm{CX} 3 \mathrm{CR} 1 ; n=6$, fractalkine). Values are expressed as mean \pm SD. $* p<0.05$.

CX3CR1 chemokine signaling, which is involved in atherogenesis and promotes SMC proliferation (22), we examined the effect of IL-15 on the expression of fractalkine and its receptor CX3CR1 mRNA, using the same samples as described above. IL-15 significantly decreased the expression of CX3CR1, but not fractalkine mRNA, in DA SMCs (Fig. 8).

\section{DISCUSSION}

The present study demonstrated that IL-15, a proinflammatory cytokine, inhibited both SMC proliferation and HA accumulation that promote NCF in the DA. IL-15 has been known to be up-regulated in both human and animal atherosclerotic lesions and to induce antigen-independent T-cell activation during atherogenesis $(20,21)$. These studies have demonstrated that IL-15 inhibits SMC migration and thus NCF. Instead of pathogenic vascular remodeling, to our knowledge, this is the first study demonstrating that IL-15 also plays a role in physiologic vascular remodeling in a developing vessel. A recent study indicated that IL-15 suppressed CX3CR1 chemokine signaling (22), which is consistent with the present result showing that IL-15 decreased the expression of CX3CR1 mRNA in DA SMCs. Because CX3CR1 chemokine signaling promotes SMC proliferation and thus NCF (30-32), the down-regulation of CX3CR1 could be, in part, a mechanism of the inhibitory effect of IL-15 on DA SMC proliferation.

Because no inflammatory cells were detected in the region where IL-15 was expressed in the DA in the present study, the mechanism of induction of IL-15 is an important question. Waleh et al. (12) demonstrated that ischemia initiated an activate inflammatory response that affected the vascular remodeling process in postnatal DA. They showed that several cytokines, including IL-8, were up-regulated in the DA wall, although the authors did not refer to IL-15 in their study (12). However, we think that IL-15 is unlikely to be induced by ischemia because the expression levels of IL-15 mRNA were predominant at e21 when blood was sufficiently supplied to DA. Instead, the present study suggested that PGE could be a trigger of physiologic induction of IL-15 in developing DA because we found that PGE stimulation increased the expression of IL-15 mRNA in DA SMCs. In this regard, previous studies have also demonstrated that PGE or cyclooxygenases regulated the expression of IL-15 in various types of cells (25-27). Because DA is more sensitive to PGE stimulation than the other vessels, our result may explain the higher 
expression level of IL-15 mRNA in the DA than in the aorta. Furthermore, we also found that IL-15 up-regulated the expression of EP4 mRNA, suggesting that there is a positive feedback loop to increase the expression of EP4 and IL-15 mRNAs without inflammation.

The second important question is why IL-15 was predominantly expressed in the IEL of DA. Angiolillo et al. (33) demonstrated that IL-15, which binds to endothelial cells, stimulates angiogenesis. Other previous studies have demonstrated that IL-15 was expressed predominantly in endothelial cells of normal carotid arteries and in the media and neointima of injured carotid arteries $(20,22)$. Although we also found that IL-15 was expressed in the media and endothelial cells in the DA, it abundantly attained the IEL in the DA. We examined the localization of IL-15 receptors, but none of them exhibited similar distribution with IL-15. TGF $\beta$ is known to bind to latent TGF $\beta$ binding proteins, which play an important role in the secretion and storage of $\operatorname{TGF} \beta$ in extracellular matrix $(34,35)$. Therefore, IL-15 may bind its unknown binding protein(s) in IEL in DA. The other possibility is that the IEL may produce IL-15 in DA. Although the precise mechanism of the abundant accumulation of IL-15 to the IEL remains unknown, it is of great interest to further investigate the role of IL-15 in the formation of elastin assembly in the DA. NCF consists of the separation of endothelial cells from the IEL and impaired elastin assembly followed by a migration of SMCs into the subendothelial region $(1,5,36)$. The failure of this process could result in the formation of a subendothelial elastic lamina, which is a common denominator in the histology of a persistent DA $(5,37)$. Further study of the role of IL-15 in the formation of a subendothelial elastic lamina in persistent DA is warranted.

It has been reported that HA production from endothelial cells is important for the start of NCF in dog DA and that no subendothelial HA accumulation was observed in the persistent DA (37). In addition to endothelial cells, we have recently demonstrated that $\mathrm{PGE}_{2}-\mathrm{EP} 4$ accumulated $\mathrm{HA}$ production from DA SMCs, which also play an important role in promoting NCF in the DA (24). The present study demonstrated that IL-15 suppressed PGE-mediated HA production in DA SMCs, which is contrary to a previous result obtained from murine microvascular venular endothelial cells (28). However, Estess et al. (28) also demonstrated that IL-15 had no effect on the expression of HA by a murine lung capillary endothelial cell line or by human umbilical vein endothelial cells. Therefore, the effect of IL-15 on HA production may vary in tissues and/or species. Although the effect of IL-15 on HA production has not been evaluated in DA endothelial cells, we assume that the IL-15-mediated suppression of HA production in SMCs would be an inhibitory factor for NCF in the DA. Our results suggested that IL-15 may inhibit this formation through suppression of SMC proliferation and HA production, as investigated in vascular injury (22). In late gestation, several stimuli including $\mathrm{PGE}_{2}$, promote $\mathrm{NCF}$ and structural closure of the vascular lumen. IL-15 may counteract such effects to prevent exceeding NCF in the DA in late gestation. In this regard, it is intriguing to investigate whether IL-15 might also contribute to the retardation of DA closure when it is further induced by inflammation because the incidence of a patent DA was higher in premature infants with inflammation (15).

In conclusion, IL-15 was predominantly expressed in rat DA, especially in the IEL. PGE may be a trigger of the induction of IL-15 in the DA. IL-15 significantly attenuated the PDGF-BB-mediated SMC proliferation and $\mathrm{PGE}_{1}$ induced HA production in a dose-dependent manner. Therefore, IL-15 might inhibit physiologic vascular remodeling processes in closing the DA and contribute to the pathogenesis of persistent DA. Further investigation is apparently required to understand the precise role of IL-15 in the vascular remodeling in the DA.

Acknowledgments. The authors are grateful to Mayumi Watanabe and Meihua Jin for excellent technical assistance.

\section{REFERENCES}

1. Smith GC 1998 The pharmacology of the ductus arteriosus. Pharmacol Rev 50:35-58 2. Gittenberger-de Groot AC 1977 Persistent ductus arteriosus: most probably a primary congenital malformation. Br Heart J 39:610-618

3. Rabinovitch M 1996 Cell-extracellular matrix interactions in the ductus arteriosus and perinatal pulmonary circulation. Semin Perinatol 20:531-541

4. Hinek A, Mecham RP, Keeley F, Rabinovitch M 1991 Impaired elastin fiber assembly related to reduced $67-\mathrm{kD}$ elastin-binding protein in fetal lamb ductus arteriosus and in cultured aortic smooth muscle cells treated with chondroitin sulfate. J Clin Invest 88:2083-2094

5. Slomp J, van Munsteren JC, Poelmann RE, de Reeder EG, Bogers AJ, Gittenberger-de Groot AC 1992 Formation of intimal cushions in the ductus arteriosus as a model for vascular intimal thickening. An immunohistochemical study of changes in extracellular matrix components. Atherosclerosis 93:25-39

6. Newby AC, Zaltsman AB 2000 Molecular mechanisms in intimal hyperplasia. J Pathol 190:300-309

7. Toutouzas K, Colombo A, Stefanadis C 2004 Inflammation and restenosis after percutaneous coronary interventions. Eur Heart J 25:1679-1687

8. Lucas AR, Korol R, Pepine CJ 2006 Inflammation in atherosclerosis: some thoughts about acute coronary syndromes. Circulation 113:e728-e732

9. Charo IF, Taubman MB 2004 Chemokines in the pathogenesis of vascular disease. Circ Res 95:858-866

10. Hansson GK 2001 Regulation of immune mechanisms in atherosclerosis Ann N Y Acad Sci 947:157-166

11. Zhou X, Robertson AK, Rudling M, Parini P, Hansson GK 2005 Lesion development and response to immunization reveal a complex role for CD4 in atherosclerosis. Circ Res 96:427-434

12. Waleh N, Seidner S, McCurnin D, Yoder B, Liu BM, Roman C, Mauray F, Clyman RI 2005 The role of monocyte-derived cells and inflammation in baboon ductus arteriosus remodeling. Pediatr Res 57:254-262

13. Clyman RI, Seidner SR, Kajino H, Roman C, Koch CJ, Ferrara N, Waleh N, Mauray F, Chen YQ, Perkett EA, Quinn T 2002 VEGF regulates remodeling during permanent anatomic closure of the ductus arteriosus. Am J Physiol Regul Integr Comp Physiol 282:R199-R206

14. Tannenbaum JE, Waleh NS, Mauray F, Gold L, Perkett EA, Clyman RI 1996 Transforming growth factor-beta protein and messenger RNA expression is increased in the closing ductus arteriosus. Pediatr Res 39:427-434

15. Gonzalez A, Sosenko IR, Chandar J, Hummler H, Claure N, Bancalari E 1996 Influence of infection on patent ductus arteriosus and chronic lung disease in premature infants weighing 1000 grams or less. J Pediatr 128:470-478

16. Gittenberger-de Groot AC, Moulaert AJ, Hitchcock JF 1980 Histology of the persistent ductus arteriosus in cases of congenital rubella. Circulation 62:183-186

17. Grabstein KH, Eisenman J, Shanebeck K, Rauch C, Srinivasan S, Fung V, Beers C, Richardson J, Schoenborn MA, Ahdieh M, et al 1994 Cloning of a T cell growth factor that interacts with the beta chain of the interleukin-2 receptor. Science 264:965-968

18. Carson WE, Giri JG, Lindemann MJ, Linett ML, Ahdieh M, Paxton R, Anderson D, Eisenmann J, Grabstein K, Caligiuri MA 1994 Interleukin (IL) 15 is a novel cytokine that activates human natural killer cells via components of the IL-2 receptor. J Exp Med 180:1395-1403

19. Giri JG, Ahdieh M, Eisenman J, Shanebeck K, Grabstein K, Kumaki S, Namen A, Park LS, Cosman D, Anderson D 1994 Utilization of the beta and gamma chains of the IL-2 receptor by the novel cytokine IL-15. EMBO J 13:2822-2830

20. Wuttge DM, Eriksson P, Sirsjo A, Hansson GK, Stemme S 2001 Expression of interleukin-15 in mouse and human atherosclerotic lesions. Am J Pathol 159:417-423

21. Houtkamp MA, van Der Wal AC, de Boer OJ, van Der Loos CM, de Boer PA, Moorman AF, Becker AE 2001 Interleukin-15 expression in atherosclerotic plaques: an alternative pathway for T-cell activation in atherosclerosis? Arterioscler Thromb Vasc Biol 21:1208-1213

22. Cercek M, Matsumoto M, Li H, Chyu KY, Peter A, Shah PK, Dimayuga PC 2006 Autocrine role of vascular IL-15 in intimal thickening. Biochem Biophys Res Commun 339:618-623 
23. Yokoyama U, Minamisawa S, Adachi-Akahane S, Akaike T, Naguro I, Funakoshi K, Iwamoto M, Nakagome M, Uemura N, Hori H, Yokota S, Ishikawa Y 2006 Multiple transcripts of $\mathrm{Ca} 2+$ channel alpha1-subunits and a novel spliced variant of the alpha1C-subunit in rat ductus arteriosus. Am J Physiol Heart Circ Physiol 290:H1660-H1670

24. Yokoyama U, Minamisawa S, Quan H, Ghatak S, Akaike T, Segi-Nishida E, Iwasaki S, Iwamoto M, Misra S, Tamura K, Hori H, Yokota S, Toole BP, Sugimoto Y, Ishikawa Y 2006 Chronic activation of the prostaglandin receptor EP4 promotes hyaluronan-mediated neointimal formation in the ductus arteriosus. J Clin Invest 116:3026-3034

25. Borger P, Vellenga E, Gringhuis SI, Timmerman JA, Lummen C, Postma DS, Kauffman HF 1998 Prostaglandin E2 differentially modulates IL-5 gene expression in activated human T lymphocytes depending on the costimulatory signal. J Allergy Clin Immunol 101:231-240

26. Min SY, Kim WU, Cho ML, Hwang SY, Park SH, Cho CS, Kim JM, Kim HY 2002 Prostaglandin E2 suppresses nuclear factor-kappaB mediated interleukin 15 production in rheumatoid synoviocytes. J Rheumatol 29:1366-1376

27. Verri WA Jr, Cunha TM, Parada CA, Wei XQ, Ferreira SH, Liew FY, Cunha FQ 2006 IL-15 mediates immune inflammatory hypernociception by triggering a sequential release of IFN-gamma, endothelin, and prostaglandin. Proc Natl Acad Sci U S A 103:9721-9725

28. Estess P, Nandi A, Mohamadzadeh M, Siegelman MH 1999 Interleukin 15 induces endothelial hyaluronan expression in vitro and promotes activated $\mathrm{T}$ cell extravasation through a CD44-dependent pathway in vivo. J Exp Med 190:9-19

29. An H, Nishimaki S, Ohyama M, Haruki A, Naruto T, Kobayashi N, Sugai T, Kobayashi Y, Mori M, Seki K, Yokota S 2004 Interleukin-6, interleukin-8, and soluble tumor necrosis factor receptor-I in the cord blood as predictors of chronic lung disease in premature infants. Am J Obstet Gynecol 191:1649-1654

30. Lesnik P, Haskell CA, Charo IF 2003 Decreased atherosclerosis in CX3CR1-/- mice reveals a role for fractalkine in atherogenesis. J Clin Invest 111:333-340

31. Liu P, Patil S, Rojas M, Fong AM, Smyth SS, Patel DD 2006 CX3CR1 deficiency confers protection from intimal hyperplasia after arterial injury. Arterioscler Thromb Vasc Biol 26:2056-2062

32. Perros F, Dorfmuller P, Souza R, Durand-Gasselin I, Godot V, Capel F, Adnot S, Eddahibi S, Mazmanian M, Fadel E, Herve P, Simonneau G, Emilie D, Humbert M 2006 Fractalkine-induced smooth muscle cell proliferation in pulmonary hypertension. Eur Respir J 29:937-943

33. Angiolillo AL, Kanegane H, Sgadari C, Reaman GH, Tosato G 1997 Interleukin-15 promotes angiogenesis in vivo. Biochem Biophys Res Commun 233:231-237

34. Michel K, Roth S, Trautwein C, Gong W, Flemming P, Gressner AM 1998 Analysis of the expression pattern of the latent transforming growth factor beta binding protein isoforms in normal and diseased human liver reveals a new splice variant missing the proteinase-sensitive hinge region. Hepatology 27:1592-1599

35. Rifkin DB 2005 Latent transforming growth factor-beta (TGF-beta) binding proteins: orchestrators of TGF-beta availability. J Biol Chem 280:7409-7412

36. Gittenberger-de Groot AC, Strengers JL, Mentink M, Poelmann RE, Patterson DF 1985 Histologic studies on normal and persistent ductus arteriosus in the dog. J Am Coll Cardiol 6:394-404

37. De Reeder EG, Girard N, Poelmann RE, Van Munsteren JC, Patterson DF, Gittenberger-De Groot AC 1988 Hyaluronic acid accumulation and endothelial cell detachment in intimal thickening of the vessel wall. The normal and genetically defective ductus arteriosus. Am J Pathol 132:574-585 